\title{
RESOLUTION OF N-PROTECTED AMINO ACID DERIVATIVES IN SUPERCRITICAL CARBON DIOXIDE CATALYZED BY "ALCALASE".
}

\author{
Shui-Tein Chen ${ }^{1, *}$, Chin-Far Tsai ${ }^{2}$, Kung-Tsung Wang ${ }^{1,2 *}$.
}

1. Institute of Biological Chemistry, Academia Sinica. P.O. Box 23-1 06, Taipei, Taiwan. 10098.

2. Department of Chemistry, National Taiwan University.

\section{Summary:}

Alkaline protease "alcalase" has been found to be very stable and active in supercritical carbon dioxide.

Procedures for resolution of $\mathrm{N}$-protected amino acid derivatives in supercritical carbon dioxide catalyzed by alcalase with high yields and optical purity have been developed.

Recently, the search for proteases that are stable in organic solvents for peptide synthesis has been the subject of extensive investigation. ${ }^{1}$ Several studies have demonstrated the possibility of using proteases to catalyze peptide synthesis in organic solvents, but a drawback of those reactions is the stability of the enzyme in organic solvents. ${ }^{2.3}$ Many immobilization processes have been developed to overcome this. We have found the industrial alkaline protease, alcalase, was very stable and reactive in supercritical carbon dioxide (SFC). This paper describes using alcalase as a catalyst for resolution of $\mathrm{N}$-protected amino acid derivatives which have an unusual side-chain. Enzymatic reaction in SFC has been studied extensively ${ }^{4}$. By using SFC as a solvent the use of hazard toxic solvents can be avoided. It is also potentially useful in industry for the purpose of environmental protection and for economic reasons due to energy savings in the evaporation of bulk solvents.

"Alcalase" is a proteolytic enzyme prepared from a selective strain of Bacillus Licheniformis. The major enzyme component in alcalase is Subtilisin Carlsberg (alkaline protease A), which is a serine protease and is widely used as additives in detergents as a digesting enzyme. ${ }^{5}$ Figure 1 shows the stability of alcalase in SFC containing $0.5 \%$ phosphate buffer $(\mathrm{pH} 8.2$ ) and the reported remaining stability of the enzyme in aqueous solution and in organic solvents. The stability of the enzyme in SFC was measured by the concentration

Abbreviation: Cbz-, carbobenzyloxy-; OMe, methyl ester; Nol, norleucine; Aba, $\alpha$-aminobutyric acid; Aca, $\alpha$-aminocapric acid; Ada, $\alpha$-aminoadipic acid; Nov, norvaline. 
increase of $\mathrm{Cbz}-\mathrm{Ala}-\mathrm{OH}$ from the hydrolyzed $\mathrm{Cbz}$-Ala-OMe with the withdrawn incubated-enzyme in phosphate buffer ( $\mathrm{pH} 9.0)$ and using the enzyme activity of the first withdrawn as $100 \%$. In a typical assay, alcalase (1 $\mathrm{mL})$, water $(1 \mathrm{~mL})$, triethylamine $(1 \mathrm{~mL})$ and dried ice $(200 \mathrm{~g})$ were put into a SFC reactor. ${ }^{6}$ After the temperature of the mixture was raised to $35^{\circ} \mathrm{C}$, a small sample of the mixture containing alcalase was released into a sample vial at each time interval, and an aliquot of the enzyme solution (100 $\mu \mathrm{L})$ was transferred to the assay solution (containing $0.1 \mathrm{M}$ substrate of Cbz-Ala-OMe in a mixture $(2 \mathrm{~mL})$ of $\mathrm{t}$ $\mathrm{BuOH} /$ phosphate buffer 2:8). The hydrolysis was conducted for 5 minutes at $25^{\circ} \mathrm{C}$, and the resulting solution was analyzed by HPLC to measure the concentration of $\mathrm{Cbz}-\mathrm{Ala}-\mathrm{OH}$. The alcalase in SFC containing $0.5 \%$ buffer had a half life time of 30 hours. This stability was enough for resolution purposes. Under the same reaction temperature, the alcalase had a half life time of $10 \mathrm{~h}$ in phosphate buffer (pH 8.2). . $^{3 \mathrm{c} d \mathrm{~d}}$

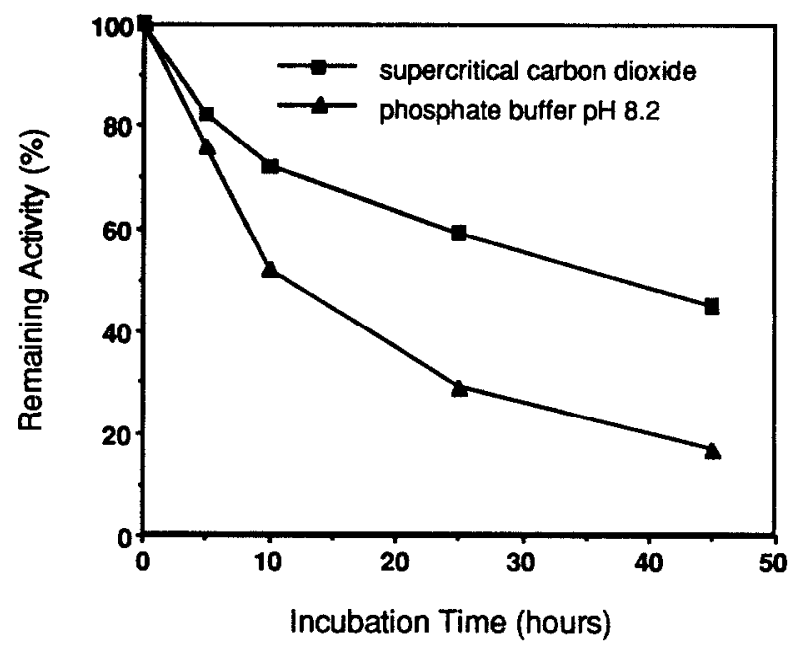

Figure 1 Stability of alculase in phosphate buffer $\mathrm{pH}=8.2$ and in SFC containing $0.5 \%$ water at $35^{\circ} \mathrm{C}$.

Amino acids, which have normal side-chains, were chosen as target compounds for resolution. The substrates were simply prepared by acylation of the amino acid with carbobenzyloxyl chloride, followed by methylation with thionyl chloride in methanol. ${ }^{7}$ The resolution was performed in SFC containing $0.5 \%$ water. ${ }^{8}$ A typical reaction of alcalase catalyzed resolution of Cbz-D,L-Aba-OMe was studied as follows: Dry Ice $(200 \mathrm{~g})$, water $(1.0 \mathrm{~mL})$, triethylamine $(1.0 \mathrm{~mL})$, alcalase $(1.0 \mathrm{~mL})$ and Cbz-D,L-Aba-OMe $(2.34 \mathrm{~g}, 10$ $\mathrm{mmol}$ ) were put into the reactor. After the pressure in the reactor reached 2-3 atm, the pressure was released to purge out the air. The procedure was repeated for three times, and then the temperature of reactor was raised to $33-35^{\circ} \mathrm{C}$ by immersing the reactor into a water bath, and the stirrer was started. The pressure in the reactor at this temperature was 78-80 atm. A small sample was taken in each time interval and analyzed by hplc. After half of the Cbz-D,L-Aba-OMe was hydrolyzed, the carbon dioxide was evaporated, and the resulting mixture was extracted with ethyl acetate $(3 \times 20 \mathrm{~mL})$ to remove unreacted Cbz-D-Aba-OMe. The aqueous layer was 
acidified $(1 \mathrm{~N} \mathrm{HCl})$ to $\mathrm{pH} 1.5-2.0$ and extracted with ethyl acetate $(3 \times 20 \mathrm{~mL})$. Each of the ethyl actate was washed with water separately, and evaporated to yield Cbz-L-Aba-OH and Cbz-D-Aba-OMe in yields of 95\% and $81 \%$ with enantiomeric excesses of $>99 \%$ and $92 \%$, respectively. In a similar manner, Cbz-D,L-Nov-OMe, Cbz-D,L-Nol-OMe, Cbz-D,L-Aca-OMe, and Cbz-D,L-Ada-OMe were resolved and obtained with yields of 80-90\%.. Figure 2 shows the time courses of the alcalase catalyzed-hydrolysis of Cbz-D,L-Aba-OMe in SFC containing $0.5 \%$ water. The reaction was conducted to about $46-48 \%$ conversion within 20 hours. The rates of hydrolysis was determined from time dependent plots of the increasing concentration of hydrolyzed $\mathrm{N}$-protected amino acid or the decreasing concentration of $\mathrm{N}$ protected amino acid ester. The progress of the reaction suggested that only one-isomer was hydrolyzed, and that this hydrolysis was not affected by the presence of the unhydrolyzed-isomer. The measurement of the specific rotation of each resolved product indicates that the alcalase catalyzed hydrolysis was stereospecific only for the esters of the L-amino acid. The enantiomeric excess of the resolved products was determined on hplc using a Chiralcel OD column. Results are shown on Table 1.

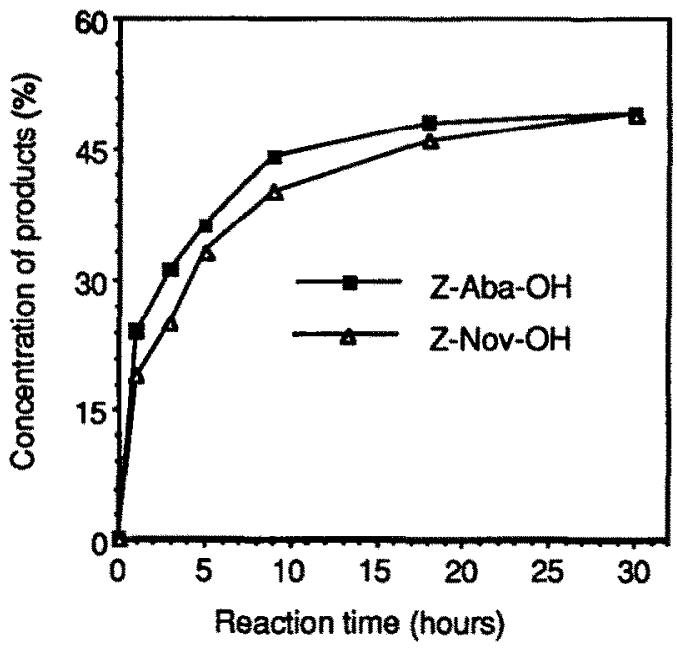

Figure 2 Time course for alcalase catalyzed resolution of $\mathrm{Cbz}-\mathrm{D}, \mathrm{L}$ $\mathrm{Aba}-\mathrm{OMe}$ and $\mathrm{Cbz}-\mathrm{D}, \mathrm{L}-\mathrm{Nov}-\mathrm{OMe}$ in supercritical carbon dioxide.

In summary, this is the first example for the enzyme-catalyzed resolution of racemic Cbz-amino acid esters in supercritical carbon dioxide. The procedure illustrated here describes a practical application of alcalase in $\mathbf{N}$-protected amino acid resolution, particularly in the resolution of hydrophobic amino acid derivatives which are insoluble in aqueous solutions. The results demonstrate that a small amount of water in the reaction solution is enough for the purpose of resolution. Most of these unnatural amino acids can not be obtained by fermentation or recombinant DNA technology. Resolution is one of the best ways to produce optically pure unnatural amino acids. The alcalase has very broad specificity at its $s_{1}{ }^{\prime}$-subsite ${ }^{5}$. This resolution procedure should be applicable to most other amino acids. The catalytical properties and specificity of the alcalase studied here are not limited in use to only resolution purposes. 
Table 1. Resolution of Cbz-D,L-amino acid in supercritical carbon dioxide.

Entry* Substrate

Product

\begin{tabular}{|c|c|c|c|c|c|}
\hline $\mathrm{Cbz}_{\mathrm{N}}^{\mathrm{H}} \stackrel{\mathrm{R}}{\mathrm{L}=} \mathrm{COOCH}_{3}$ & $\begin{array}{l}\text { (hour) } \\
\text { (action time }\end{array}$ & $\begin{array}{c}\text { Cbz-N- } \\
\text { Conversion } \\
(\%)\end{array}$ & $\begin{array}{l}\mathrm{COOCH}_{3} \\
\text { e. e. }\end{array}$ & ${ }_{-1}^{H}$ & $\mathrm{E}^{+}$ \\
\hline $1-\mathrm{CH}_{2}-\mathrm{CH}_{3}$ & 18 & 48 & 92 & $>99$ & $>650$ \\
\hline $2-\left(\mathrm{CH}_{2}\right)_{2}-\mathrm{CH}_{3}$ & 20 & 46 & 88 & 99 & 535 \\
\hline $3-\left(\mathrm{CH}_{2}\right)_{3}-\mathrm{CH}_{3}$ & 45 & 40 & 45 & 99 & 397 \\
\hline $4-\left(\mathrm{CH}_{2}\right)_{5}-\mathrm{CH}_{3}$ & 45 & 24 & 30 & 96 & 66 \\
\hline $5-\left(\mathrm{CH}_{2}\right)_{3}-\mathrm{COO}-\mathrm{CH}_{3}$ & 48 & 53 & 72 & 82 & 33 \\
\hline
\end{tabular}

t: e. e. : enantiomeric excess, $E=\ln \left[1-c\left(1+e_{\mathrm{p}}\right)\right] / \ln \left[1-\mathrm{c}\left(1-\mathrm{ee}_{\mathrm{p}}\right)\right]$ see ref 9 .

$\#: \mathbf{L}=\mathrm{Aba} ; \mathbf{2}=$ Nov; $\mathbf{2}=\mathrm{Nol} ; \mathbf{4}=\mathrm{Aca} ; \mathbf{3}=\mathrm{Ada}$.

Physical data and analysis conditions for each product are listed as: i) $\mathrm{mp}:{ }^{\circ} \mathrm{C}$, ii) ${ }^{i} \mathrm{H}-\mathrm{nmr}\left(\mathrm{CDCl}_{3}\right)$ and ii) Hple conditions for e.e. determinationon on Chiral OD column, eluent: n-Hex:IPA:Formic acid.

Cbz-D-Aba-OMe: i) 33-35; ii) $8,0.90$ (t 3H), 1.65-1.86 (m 2H), 3.69 (s 3H), $4.31(\mathrm{~m} 1 \mathrm{H}), 5.08$ (s $2 \mathrm{H})$, 5.40 (d $1 \mathrm{H}), 7.25-7.35$ (m $5 \mathrm{H}) ;$ iii) $60 ; 40: 0$.

Cbz-L-Aba-OH: i) 57-59; ii) $8,0.95$ (t 3H), 1.69-1.95 (m 2H), 4.35 (m 1H), 5.10 (s 2H), 5.32 (d 1H), 7.25-7.35 (m 5H); iii) 60:40:0.2.

Cbz-D-Nov-OMe: i) 42-44; ii) $\delta, 0.91$ (t 3H), 1.35 (m 2H), 1.58-1.82 (m 2H), 3.71 (s 3H), 5.09 (d 1H), 5.24 (d 1H), 7.25-7.35 (m, 5H); iii) 70:30:0.

Cbz-L-Nov-OH; i) 84-86; ii) $\delta, 0.90$ (t 3H), 1.37 (m 2H), 1.61-1.90 (m 2H), 4.39 (m 1H), 5.10 (s 2H), 5.30 (d 1H), 7.25-7.35 (m 5H); iii) 60:40:0.2.

Cbz-D-Nol-OMe: i) 65-67; ii) $8,0.87$ (t 3H), 1.20-1.35 (m 4H), 1.60-1.84 (m 2H), 3.39 (s 3H), 4.35 (m 1H), 5.09 ( $\mathrm{s} 2 \mathrm{H}), 5.30$ (d 1H), 7.25-7.35 (m, 5H); iii) 80:20:0.

Cbz-L-Nol-OH: i) $98-100$; ii) $\delta, 0.88$ (t 3H), 1.25-1.35 (m 4H), 1.60-1.90 (m 2H), 4.37 (m 1H), 5.10 (s $2 \mathrm{H}), 5.31$ (d 1H), 7.25-7.35 (m 5H); iii) 60:40:0.2.

Cbz-D-Aca-OMe: i) oil; ii) $8,0.85$ (t 3H), 1.20-1.30 (m 8H), 1.60-1.84 (m 2H), 3.71 (s 3H), 4.35 (m 1H), 5.09 (s 2H), 5.29 (d 1H), 7.25-7.35 (m, 5H); iii) 80:20:0.

Cbz-L-Aca-OH: i) oil; ii) $\delta, 0.84$ (t 3H), 1.18-1.30 (m 8H), 1.60-1.90 (m 2H), $4.36(\mathrm{~m} 1 \mathrm{H}), 5.09$ (s 2H), 5.29 (d 1H), 7.25-7.35 (m 5H); iii) 75:25:0.2.

Cbz-D-Ada-OMe: i) oil; ii) $8,1.57-1.88$ (m 4H), 2.31 (t 2H), 3.64 (s 3H), 3.72 ( s 3H), 4.37 (m 1H), 5.09 (s 2H), 5.34 (d 1H), 7.25-7.35 (m 5H); iii) 60:40:0.

Cbz-L-Ada-OH: i) oil; ii) $\delta, 1.65-1.90$ (m 4H), 2.34 (t 2H), 3.35 (s 1H), 4.37 (m 1H), 5.10 (s 2H), 5.35 (d $1 \mathrm{H}), 7.25-7.35$ (m $5 \mathrm{H})$; iii) $60: 40: 0.2$. 


\section{Acknowledgement}

Support for this research provided by the National Science Council of Taiwan is gratefully acknowledged.

References.

1). a) C. H. Wong, K. T. Wang, Experientia, 1991, 47, 1123.

b) V. Schellenberger, H. D. Jakubke, Angew Chem, Int. Ed. Engl. 1991, $30,1437$.

c) A. M. Klibanov. Chemtech. 1986, 16 . 354.

d) L. E. S. Brink, J. Tramper, K. Ch. A. M. Luyben, K. V. Riet, Enzyme Microb. Technol. 1988, $10,736$.

e) Y. L. Khmelnitsky, A. V. Levashov. N. L. Klyachko, K. Martinek, Enzyme Microb. Technol. $1988,10,710$.

f) M. N. Gupta, Eur. J. Biochem. 1992, 203, 25.

g) M. Waks, Proteins: Structure, Function, and Genetics, 1986, 1, 4.

h) J.S. Dordick, Biotechnol. Prog. 1992, 8, 259.; i) S. H. M.V. Erp, E.O. Kamenskaya, Y. L. Khmelnitsky, Eur. J. Biochem. 1991, 202, 379.

2). a) P. Kuhl, P. J. Halling, H. D. Jakubke, Tetrahydron Letters 1990, 31, 5213.

b) R. Affleck, Z .F. Xu, V. Suzawa, K. Focht, D. S. Clark, J.S. Dordick, Proc. Natl. Acad. Sci.USA, 1992, 89, 1100.

c) H. Kitaguchi, A. M. Klibanov, J. Amer. Chem. Soc. 1989, 111 , 9272.

d) M. Stahl, M. O. Mansson, K. Mosbach, Biotech. Letters, 1990, $12(3), 161$.

e) H. Kise, Bioorg. Chem. 1990, 18, 107.

f) H. Kise, Y. Tomiuchi, Biotech. Letters 1991, 13, 317.

g) T. Nagashima, A. Watanabe, H. Kise, Enzyme Microb. Technol., 1992, 14. 842.

h) Z. Zhong, J. J. C. Liu, L. M. Dinterman, M. A. J. Finkelman, T.W. Mueller, M. L. Rollence,M. Whitlow, C.H. Wong, J. Amer. Chem. Soc. 1991, $113,683$.

i) C. H. Wong, S. T. Chen, W. J. Hennen, J. A. Bibbs, Y. F. Wang, J. L. C. Liu, M. W. Pantoliano, M. Whitlow, P. N. Bryan, J. Amer. Chem. Soc. 1990, 112, 945.

j) R.S., Phillips, M.S. Matthews, E. Olson, R.L.V. Tersch, Enzyme microb. Technol. 1990, 12 , 731.

k) K. Chen, F.H. Arnold, Biotechnology, 1991, 9, 1073.

3). a) T. Sakurai, A. L. Margolin, A. J. Russell, A. M. Klibanov, J. Amer. Chem. Soc. 1988, 110 , 7236.

b) P.A. Fitzpatrick, A. M. Klibanov, J. Amer. Chem. Soc. 1991, 113, 3166.

c) S. T. Chen, S. C. Hsiao, K. T. Wang, Bioorg. \& Med. Chem. Letters. 1991, 1(9), 445.

d) S. T. Chen, S. Y. Chen, K. T. Wang, J. Org. Chem. 1992, 57, 6960.

e) A.M. Klibanov, TIBS 1989, April, 141.

f) S. Riva, J. Chopineau, A.P.G. Kieboom, A.M. Klibanov, 1988, 110, 584.

g) A.L. Margolin, D.F. Tai, A.M. Klibanov, J. Amer. Chem. Soc. 1987, $109,7885$.

4) a) O. Aaltonen, M. Rantakyla, Chemtech, 1991, April, 240.

b) M. Taniguchi, M. Kamihara, T. Kobayashi, Agric. Biol. Chem. 1987, 51 (2), 593.

c) Y. M. Chi, K. Nakamura, T. Yano, Agric. Biol. Chem. 1988, 52(6), 1541.

d) Y. Ikushima, N. Saito, T. Yokoyama, K. Hatakeda, S. Ito, M. Arai, H. W. Blanch, Chem Letter. $1993,109$.

e) A. Marty, W. Chulalaksananukul, J. S. Condoret, R. M. Willemot, G. Durand, Biotech. Letters, 1990,12(1), 11 .

f) T. Dumont, D. Barth, C. Corbier, G. Branlant, Biotech. Bioeng. 1992, 39, 329.

g) A. Marty, W. Chulalaksananukul, R. M. Willemot, J. S. Condoret, Biotech. Bioeng. 1992, 39, 273.

h) T. W. Randolph, D. S. Clark, H. W. Blanch, J. M. Prausnitz, Science, 1988, 238, 387.

i) S. V. Kamat, B. Iwaskewycz, E. J. Beckman, A. Russell, Proc. Ntal. Acad. Aci. USA, 1993, 90, 2940.

j) S. Kamat, J. Barrera, E. J. Beckman, A. J. Russell, Biotech. Bioeng. 1992, $40,158$.

k) D. A. Miller, H. W. Blanch, J. M. Prausnitz, Ind. Eng. Chem. Res. 1991, 30, 939.

1) H. S. Lee, W. G. Lee, S. W. Park, H. Lee, H. N. Chang, Biotech. Letters, 1993, 7 (4), 267.

m) P. Pasta, G. Mazzola, G. Carrea, S. Riva, Biotech. Letters, 1989, $11(9), 643$. 
5). Philipp, M., Bender, M. L., Molecular \& Cellular Biochem. 1983, 51, 5.\& references, cited herein. Alcalase was purchased from NOVO industrial (Denmark) as a brown liquid with a specific activity of 2.5 AU./mL. (According to NOVO, one Anson-unit (AU) is the amount of enzyme which, under standard conditions, digests haemoglobin at an initial rate liberating per min an amount of TCA-soluble product, which gives the same color of phenol reagents as 1 mequiv of tyrosine. Thus, $1 \mathrm{AU}=1000 \mathrm{U}$, $1 \mathrm{U}=1 \mathrm{mmol}$ of L-Tyr-OMe hydrolyzed per min).

6) The reactor was modified from a high pressure with an sample outlet to withdraw the sample during the reaction. We have used this reactor to conduct enzymatic hydrolysis, enzymatic transesterification, and enzymatic peptide bond formation (unpublished data).

7) Bodanszky, M., Bodanszky, A., (1984) in "The Practice of Peptide Synthesis" Springer-Verlag, Berlin, Heidelberg, New York Tokyo.

8) Figure 3 shows the reactor, which was modified from a simple high pressure reactor $(750 \mathrm{~mL}$, Max pressure $200 \mathrm{~atm}$ ) by introduceing a new vent that was regulated using a needle valve. The connection tube of the vent was inserted deeply near the bottom of the reactor, so that samples could be released to monitor the progress of the reaction during the reaction

9) Chen, C. S., Fujimoto, Y., Girkaudas, G., Sih, C. J., J. Amer. Chem. Soc. 1982, 104, 7294.

Figure 3.

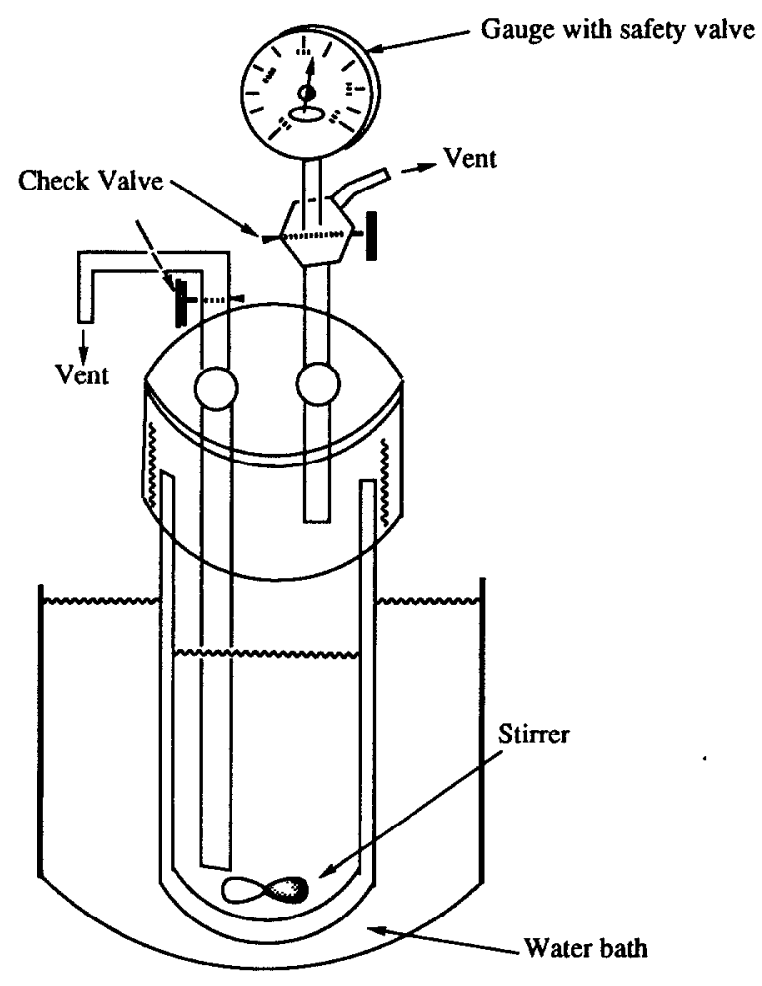

(Received in USA 22 October 1993; accepted 30 December 1993) 